\title{
СОЦИАЛЬНОЕ ОБОСНОВАНИЕ ПОЗИТИВНОЙ ЮРИДИЧЕСКОЙ ОТВЕТСТВЕННОСТИ
}

\begin{abstract}
Аннотация: Статья посвящена социальным основаниям позитивной юридической ответственности, без которой не возможно построение правового государства и формирование гражданского общества. Автор отстаивает правовую природу позитивной юридической ответственности, используя богатый соииологический и философский материал. Одновременно ведется полемика с ученыли-социологами и философами, которые при разработке общей концепции социальной ответственности не учитывают особенности юридической ответственности. Предметом исследования также являются различные разновидности сочиальных норм, в том числе, и юридические, в которых устанавливается позитивная ответственность В процессе исследования использовань диалектический метод, сравнительно-правовой метод, сочиилогический. В работе приведене результать анкетирования. В статье даются авторские определения сочиальной и юридической ответственности, приводятся даннье анкетирования различных категорий граждан и экспертов (ученых-юристов, практических работников) по вопросам позитивной юридической ответственности и ее регулирующего воздействия. Автором обосновывается единьий характер юридической ответственности, которая включает позитивную (добровольную) и негативную (государственно-принудительную) формы реализации. Статутная (единая) ответственность-это объективно обусловленная, установленная законом и охраняемая государством обязанность (необходимость) соблюдения правовых предписаний участниками правоотношений, а в случае ее нарушения - обязанность правонарушителя претерпеть осуждение, ограничение прав имущественного или личного неимущественного характера.
\end{abstract}

Ключевые слова: Сочиальная ответственность, позитивная ответственность, формы реализации ответственность, юридическая ответственность, долг, необходимость, свобода воли, негативная ответственность, статутная ответственность, правовой долг.

Abstract: This article is dedicated to the social bases of positive legal responsibility, without which building a legal state and forming a civil society is impossible. The author defends the legal nature of positive legal responsibility using the rich social and philosophical material. The author simultaneously conducts a polemic with scientists-sociologists and philosophers, who while devising the general concepts of social responsibility, do not take into consideration the specificity of legal responsibility. The subject of the research also includes various types of social norms, including juridical, which contain positive responsibility. The work presents results of polling. The article gives original definitions to social and legal responsibility, presents the polling data from different categories of citizens and experts (legal scholars) on the issues of positive legal responsibility and its regulatory impact. The author justifies a unified character of legal responsibility, which includes the positive (voluntary) and negative (state mandatory) forms of realization. The statutory (unified) responsibility is the responsibility (requirement) to uphold the legal rules by the parties of legal relations that is objectively justified, and set by the law, which if violated, forces the violator to suffer judgement, limitation of rights of property or personal non-property nature.

Keywords: Necessity, debt, legal liability, forms of responsibility implementation, positive responsibility, social responsibility, free will, negative responsibility, statutory responsibility, legal debt.

сследование феномена юридической ответственности невозможно без уяснения ее родового понятия - социальной ответственности, «самой близкой, исходной абстракции, родового понятия, содержащего основной генетический код любого вида ответственности. Юридическую ответственность необходимо изучать во взаимосвязи с социальной, привнося при этом в понятие социальной ответственности юридическую специфику, так как зачастую философы, социологи, давая определение социальной ответственности отражают только те черты, которые характеризуют моральную, политическую и другие виды ответственности, но не полностью отражают признаки юридической ответственности, а в свою очередь ученые-юристы часто не принимают во внимание общее понятие социальной ответственности. Во многом это обусловлено тем, что очень долгое время, вплоть до середины 60-х годов двадцатого века, юридическая ответственность рассматривалась только как следствие правонарушения. Полемизируя с учеными правоведами, Р. Косолапов и В. Марков справедливо указывают, что «юристы увлеклись «самой ретроспективнейшей 


\section{Право и политика 5 (185) • 2015}

из ответственностей» - уголовной ответственностью за преступление. И именно этот аспект ответственности рассматривается чуть ли как не единственный - просто потому, что недостаточно разработана проблема ответственности в целом, в ее позитивном аспекте» [1, с. 68]. Во многом это утверждение не утратило актуальности и в настоящее время.

Примечательно, что мнение самих граждан о наличии у них позитивной ответственности расходится с представлением об этом феномене некоторых ученыхюристов. Всего было проанкетировано 400 граждан, разного возраста и обладающих различным социальным положением, и правовым статусом, а также в качестве экспертов были проанкетированы 400 человек, среди которых преподаватели-юристы, ученые-юристы, практические работники (судьи, прокуроры, работники полиции). Анкетирование граждан проводилось на территории г. Тольятти, в 2014 году, в качестве экспертов были проанкетированы ученые и практические работники, проживающие в Самарской области, а также научные сотрудники Саратовского филиала Института государства и права РАН.

Так, на вопросы о том, что в будущем может удержать от совершения правонарушения 73,4 \% от количества опрошенных ответили: знание закона; уважение закона. Более 89 \% процентов опрошенных в той или иной степени в своей повседневной жизни сопоставляют свое поведение с уголовно-правовыми и иными запретами. При этом ученые-юристы и практические работники, при проведении анкетирования, очевидно, следуя научным традициям и школам почти в половине случаев (41\%) указали, что нормы запрещающих отраслей права не регулируют поведение субъекта. Получается интересная ситуация, когда сами адресаты правовых норм считают себя позитивно-ответственными за будущее поведение, а ученыеюристы практически в своей половине не считают их таковыми. Часть ученых-юристов и практических работников считают, что запреты соблюдаются ввиду привычного поведения - $43 \%$; по мотивам уважения закона и высокой сознательности - 24, 5 \%. Между тем, сами граждане $(80,2 \%)$ указывают, что несут юридическую ответственность перед государством, подразумевается именно позитивная ответственность, за будущие действия, а 50 \% граждан указали, что и государство несет перед ними ответственность. На контрольный, дублирующий вопрос: считаете ли вы себя юридически ответственным за свое будущее поведение 84 \% проанкетированных граждан ответили положительно.
Указанное анкетирование, на наш взгляд, подтверждает многие теоретические положения о социальной позитивной ответственности, юридической ответственности как разновидности социальной ответственности, которые были получены при помощи другого методологического инструментария. Еще Иммануил Кант писал: «Человек ответственен за человечество в своем лице» [2, с. 478]. Ответственность бывает за прошлое и за будущее поведение. Поступки, совершаемые человеком, можно подразделить на те, которые он уже совершил, и те, которые может совершить в будущем. В литературе по философским, этическим, моральным, юридическим проблемам категория «ответственность» рассматривается в двух аспектах: ответственность за прошлое поведение, противоречащее социальным нормам - ретроспективная ответственность; и ответственность за будущее поведение - перспективная, позитивная ответственность. О.Э. Лейст и другие ученые, отрицая позитивную юридическую ответственность, указывает, что «правоведение, как и все общественные науки, не может просто в «готовом виде» использовать философские понятия и категории без учета специфики предмета своей науки» [3, с. 536]. Многие философские категории (в том числе и «ответственности») не учитывают специфику той или иной науки, но в то же время основные черты, признаки, аспекты, характерные для социальной ответственности находят свое проявление в юридической ответственности.

Философы справедливо указывают юристам, что ответственность «задним числом» может уберечь от проступка в будущем, но удовлетворить потребности общества она не в состоянии. Поэтому более перспективным представляется другой анализ понятия ответственности, определение ее положительной стороны, связанной с предвидением результатов своей деятельности и осмысления ее общественной значимости [4, с. 72], выражением которых выступает социально полезное поведение. Для содержательной характеристики ответственности важна не только оценка своего предполагаемого поведения, но и само действие согласно этой оценке и предвидению. И.А. Ильин именует позитивную и негативную ответственность «предварительной» и «последующей». «Предварительная ответственность есть живое чувство предстояния и призванности, стремление к совершенствованию. Еще не совершив поступка, человек уже знает о своей ответственности» $[5$, с. 305$]$. Анализ позитивной ответственности как социальной, так и юридической имеет не только теоретическое, но и практическое значение. Важнее и целесообразнее предупредить 
об наступлении негативной ответственности и с помощью позитивной ответственности предотвратить нежелательный вариант поведения, чем применять реальные меры общественного и государственноправового принуждения. Интересы профилактики социальных отклонений побуждают к исследованию механизмов формирования и обеспечения социально полезных, одобряемых обществом поступков. Одним из признаков гражданского общества выступает высокая взаимная социальная ответственность как личности перед обществом, так и общества перед личностью. Без постановки проблемы именно таким образом нельзя эффективно разрешить задачу построения гражданского общества и правового государства.

Расширение границ свободы, которые обусловлены демократизацией нашего общества, одновременно требует и повышение связанности как самого общества в целом, так личности в отдельности, предъявляемыми к ним требованиями и ответственностью. Социальная ответственность - мера свободы. С одной стороны, она предполагает свободу и основывается на ней, а с другой, ограничивает ее, побуждая или принуждая субъекта действовать в рамках предоставленной свободы. «Сознание - свобода - выбор, эта локковская триада является совокупным описанием ситуации разумного (ответственного) существования человека» [Цит. по: Царьков, 6, с. 21]. Полной или абсолютной свободы не существует. Свобода без ответственности превращается в произвол и хаос.

Как ответственность личности, так и ответственность общества и государства имеют социальную природу. Она предопределена общественным характером отношений, особенностями личности, ее местом в системе общественных отношений, особенностями самого общества. Коренные преобразования, происходящие в нашем обществе, расширяющие объем свободы субъекта предъявляют к нему и новые, более высокие требования. Это обусловлено историческим ходом развития нашего общества, усложнением общественных отношений, прогрессом в научно-технической сфере.

Концепция позитивной ответственности не теоретическая абстракция и не порождение социалистического строя как это хотят представить ее противники, а объективное отражение в научных знаниях социальной действительности, определенного этапа развития нашего общества. Не ученые породили это явление, а общественные отношения, необходимость их регулирования, совершенствования и охраны. С объективной стороны социальная ответственность отражает природу общества и человека. Ее возникновение возможно при условии предварительного предъявления к поведению людей определенных требований, закрепленных в социальных нормах. Ответственность обусловлена уровнем развития общественного сознания, уровнем социальных отношений, существующими социальными институтами. Когда субъект социальных отношений несет ответственность, в нем отражаются социальные связи и отношения. Социальная ответственность выражает определенное отношение между личностью и обществом интегрально. Специфика конкретных видов социальной ответственности обусловлена природой тех общественных отношений, внутри которых они возникли и существуют в своей качественной определенности.

В философской и социологической литературе неоднократно отмечалось, что первой фундаментальной работой по проблеме социальной ответственности стала кандидатская диссертация А.П. Чермениной. Она определяет социальную ответственность как «отношение ограничения вольности каждого индивида с позиции интересов общества, как наложение воли общества на свободную волю индивида, направление его активности в определенные рамки» [7, с. 12]. Свобода воли является предпосылкой ответственности, но на наш взгляд, нельзя сводить всю социальную ответственность только к ее позитивному содержанию. В этом случае позитивная ответственность теряет один из своих методов обеспечения - негативную ответственность. «Ретроспективная (негативная) ответственность может рассматриваться как специфический метод обеспечения ответственности позитивной» [8, с 299]. Ведь позитивная социальная ответственность, лишенная своего метода обеспечения превращается в декларацию и не способна выполнять функцию регулирования общественных отношений.

В реальной действительности существует взаимосвязь между личностью и обществом, без которой невозможно построить правовое государство и гражданское общество. Социальной обязанности ответственного субъекта корреспондирует его право на общественное содействие, на поддержку и охрану той деятельности, которая ему поручена, и которую он правомерно и добросовестно осуществляет. Между тем, способность предвидения есть не сама ответственность, а характеристика психики человека, уровня его развития. Эта способность характеризует субъекта социальной ответственности, является условием ее реализации. Все разновидности социальных норм рассчитаны только на осознанное поведение. Они оказывают воздействие на лиц, способных их осознавать. 


\section{Право и политика 5 (185) • 2015}

В.И. Сперанский, рассматривая ответственность как общеметодологическое понятие, подчеркивает, что социальная ответственность подразделяется на две подсистемы отношений. В первой - ответственность носит ретроспективный характер, выступает как социальная подотчетность и как санкция за действия, идущие вразрез с интересами общества. Во вторую подсистему входят взаимосвязи между людьми, коллективами, общностями, основанными на сознательном отношении к деятельности, совершаемой в соответствии с потребностями общества и отдельной личности. Вторая система базируется на внутренней регуляции поведения индивида, на относительно устойчивых правилах человеческого общежития, на моральных нормах [9, с 17]. Социальной ответственности личности характерно чувство долга, но оно выступает только одним из ее признаков, а поведение индивида регулируется не только моральными, но и правовыми нормами, роль которых из года в год возрастает. Социальная позитивная ответственность основывается на тех требованиях, которые предъявляют общество, государство к индивиду, и выражается она в социально одобряемом, социально значимом поведении. Моральные установки личности являются лишь признаками, характеризующими восприятие ответственности (ее субъективную сторону). Причем они не всегда обязательны, т. к. личность может совершать положительные поступки не из высоких нравственных идеалов, а из-за боязни осуждения его обществом.

Позитивная ответственность тесно связана с социальной активностью личности, которая избирается на основе предъявляемых к личности требований, изложенных в социальных нормах. Социальная норма предоставляет свободу, связывает субъекта своими требованиями и одновременно ограничивает его поведение.

Под социальной ответственностью необходимо понимать обязанность по соблюдению субъектами общественных отношений требований социальных норм, реализующаяся в их правомерном поведении, а в случаях безответственного поведения, не соответствующего предписаниям этих норм, нарушающего общественный порядок, претерпевание виновным лишений личного или имущественного характера. В этом определении аккумулируются обе стороны ответственности - позитивная и негативная. Кроме того, из этого следует, что реальным содержанием позитивной ответственности выступает соблюдение субъектом общественных отношений социальных норм, т. е. социально полезное, одобряемое поведение. Через деяние личности проявляется его отношение к установленным социальными нормами правилам.
В позитивной социальной ответственности отражаются, как долг и обязанность, так и само социально значимое действие субъекта ответственности. Все они в конечном счете и образуют статические и динамические характеристики социальной ответственности.

В литературе позитивную и негативную ответственность стали называть различными сторонами одного целостного явления. Некоторые авторы пишут о том, что ответственность имеет различные аспекты (позитивный и негативный). При этом целостное явление делится на определенные виды. В действительности, ответственность представляет единство позитивного и негативного (добровольного и принудительного), в котором негативное является своеобразным средством обеспечения позитивного. Социальная ответственность едина, но имеет две формы реализации добровольную - выражающуюся в обязанности субъекта следовать предписанием социальных норм, его правомерном поведении и реакции на него и принудительную - выражающуюся в обязанности нарушителя социальных норм подвернуться разнообразным мерам общественного и (или) государственного принуждения, понести неблагоприятных последствия и реализация этих последствий.

Схематично содержание добровольной формы реализации социальной ответственности можно отобразить следующим образом: требования, изложенные в социальных нормах - осознание субъектом предъявляемых требований - исполнение данной обязанности (совершение социально-полезных, одобряемых поступков) - реакция со стороны общества (оценка - одобрение или поощрение). Определенные границы ответственности составляет объем исполнения обязанностей и объем применяемых обществом одобрений и поощрений. В свою очередь этот объем устанавливается социальными нормами. Содержания принудительной формы реализации социальной ответственности нам представляются так: обязанность, претерпеть неблагоприятные последствия, вытекающая из факта совершения проступка, - осуждение обществом нарушителя социальных норм (оценка) - принуждение его к должному поведению - претерпевание нарушителем неблагоприятных последствий.

Формы реализации единой социальной ответственности не являются взаимоисключающими, что не могут существовать в рамках единого явления - социальной ответственности. Общность состоит в их закреплении социальной нормой, в единых предпосылках и выражении во вне в поведении субъекта. Это поведение не одинаковое по своим характеристикам. Оно может быть конфликтным, а может быть и социально одобря- 
емым, но социально одобряемое поведение существует постольку, поскольку конфликтное поведение запрещено социальной нормой. Внешние противоречивые характеристики этих разновидностей поведения обусловлены философским законом единства и борьбы противоположностей. Однако оба варианта поведения смоделированы в социальной норме, как смоделированы в ней добровольная и принудительная формы реализации социальной ответственности.

В социологической и философской литературе в целом правильно понимается добровольная (позитивная) форма реализации социальной ответственности, но часто один из ее признаков выдается за главный и доминирующий, а при определении ответственности акцент делается именно на нем. Так у одних ученых это свобода воли, у других - поведение, у третьих взаимосвязь с обществом, у четвертых - социальные требования, и наконец пятые-акцентируют внимание на осознании предъявляемых требований. Полагаю, что в понятие добровольной формы реализации социальной ответственности должны быть включены следующие признаки: социальная ответственность отражает взаимосвязь общества и личности, личности и общества; социальная ответственность состоит в обязанности субъектов социальной действительности следовать предписаниям социальных норм; социальная ответственность во вне выражается в полезном или одобряемом поведении; социальная обязанность рассчитана на осознанное и волевое поведение; по внутренним (субъективным) характеристикам социальная ответственность выражается в психическом отношении субъекта, мотивах, целях, эмоциональном фоне; во вне выражением социальной ответственности выступает оценка поведения обществом (одобрение и (или) поощрение).

Принудительная форма реализации социальной ответственности характеризуется следующими признаками: социальная ответственность - есть социальная обязанность претерпевать меры общественного воздействия, предусмотренные социальной нормой; социальная ответственность сопряжена с общественным принуждением; во вне социальная ответственность выражается в оценке обществом совершенного поступка и реальном претерпевании неблагоприятных последствий самого разнообразного характера.

С учетом изложенного считаем, что социальная ответственность - это диалектическая взаимосвязь между личностью и обществом, характеризующаяся взаимными правами и обязанностями по соблюдению предписаний социальных норм, их выполнение, влеку- щее одобрение, поощрение, а в случаях безответственного поведения, не соответствующего предписаниям этих норм, - обязанность претерпеть неблагоприятные последствия и их претерпевание.

Общие черты социальной и юридической ответственности можно выявить на основе функций и принципов. Так, в философской литературе выделяют стимулирующую (регулятивную), превентивную функции социальной ответственности [10, с. 206]. А.Ф. Плахотный, Н.С. отмечает, что для социальной ответственности преимущественно характерна регулятивная функция $[11$, с $72 ; 12$, с. 13]. Функции социальной ответственности в юридической ответственности проявляются в виде регулятивной, превентивной, карательной, восстановительной, воспитательной функций [13, с. 6].

Социальная ответственность основывается на принципах справедливости, гуманизма, необходимости [6, с.]. «Ответственность есть мера свободы, справедливости, гуманизма. В этих нравственных качествах она наиболее тесно соприкасается с идеей естественного права, которое, как известно, рассматривает нравственные принципы как постоянные и неизменные, категорические императивы, определяющие поведение человека» 14, с. 68]. Юридическая ответственность как вид социальной ответственности трансформирует в себе идеи справедливости, гуманизма, как общечеловеческие ценности и основывается на них, но одновременно ввиду ее формальной определенности она исходит и из принципов законности, индивидуализации, неотвратимости, виновности деяния [15, с. 6]. Принципы законности, индивидуализации, неотвратимости, виновности деяния обусловлены существованием принципов справедливости и гуманизма как социальной, так и юридической ответственности.

«Социальная ответственность личности есть выражение объективной зависимости индивида от общества». $[16$, c. 25]. Это положение относится и к юридической ответственности. В процессе жизнедеятельности между людьми, государством, коллективами и т.д. возникают отношения, которые закрепляются в правовых нормах. В правовых нормах закрепляется ответственность как по горизонтали, так и по вертикали. Государство и гражданин, сами граждане взаимоответственны друг перед другом. Взаимная ответственность личности и государства возведена в разряд общеправового принципа, закрепленного в Конституции РФ, который находит свою конкретизацию в иных нормативно-правовых актах и Постановлениях Конституционного Суда РФ.

Из изложенного следует, что юридическая и социальная ответственность имеют схожие основания, 
DOI: $10.7256 / 1811-9018.2015 .5 .14470$

При цитировании этой статьи сноска на доі обязательна

\section{Право и политика 5 (185) • 2015}

основываются на одинаковых предпосылках, обладают общими функциями и принципами, отражают связь общества и личности и служат достижению единых целей. Вместе с общими юридическая ответственность обладает рядом специфических признаков, которые позволяют выделять ее среди других видов социальной ответственности. Во-первых, юридическая ответственность основывается на правовых нормах, формально определена и обладает четкостью, детализированностью, и общеобязательностью; Во-вторых, юридическая ответственность гарантируется государством. В-третьих, юридическая ответственность обеспечивается государственным принуждением или государственным убеждением. В-четвертых, юридическая ответственность своими последствиями влечет государственное одобрение, поощрение или осуждение и наказание. В-пятых, юридическая ответственность осуществляется в процессуальной форме. Мы назвали не все признаки юридической ответственности, а только те, которые позволяют выделить ее среди других видов социальной ответственности, но одновременно в числе этих признаков мы объединили признаки, характеризующие как добровольную, так и государственно-принудительную формы реализации ответственности. Отличительные черты и свойства, которые выделяют юридическую ответственность среди других видов социальной ответственности, не вступают в противоречие с общими свойствами социальной ответственности.

Интересы профилактики социальных отклонений побуждают к исследованию механизмов формирования и обеспечения социально полезных, одобряемых обществом поступков. Одним из признаков гражданского общества выступает высокая взаимная социальная ответственность как личности перед обществом, так и общества перед личностью, как государства перед личностью, так и личности перед государством. Без постановки проблемы именно таким образом нельзя эффективно разрешить задачу построения гражданского общества и правового государства.

Как уже отмечалось социальная ответственность и юридическая ответственность соотносятся между собой как категории рода и вида. В таком понятийном ряду род представляет нечто общее в предметах, составляющих его виды. Понятие, относящееся к категории «вида», обладает свойствами, признаками понятий, которые находятся на более высоком уровне, но вместе с тем имеют и свои отличительные черты. В суждениях сторонников только ретроспективной юридической ответственности имеются логические противоречия. Так, признавая, что в содержание общесоциологического понятия, наряду с ретроспективным, входит и перспективный аспект, они в то же время отрицают наличие перспективного аспекта юридической ответственности. Согласно традиционной логике, признаки, отмеченные у определенного рода явлений в общем понятии, обязательно имеются и у специфических явлений данного класса. Таким образом, если мы определяем добровольную (позитивную) и принудительную (негативную) формы реализации ответственности в общесоциологическом понятии, то эти формы обязательно, согласно правилам логики, должны быть и у видовых понятий ответственности. «Ответственность - социальный феномен, имеющий двойственную природу и выступающий как социальное отношение и как качество личности. Социальная ответственность - порождение и важнейший компонент гражданского общества, общества равных свободных индивидов. Будучи с необходимостью опосредованной государством и правом, она получает политические и правовые особенности, формы» [17. с 14], но не теряет при этом своих основных признаков и характеристик.

Сторонники только негативной ответственности утверждают, что в едином понятии, явлении невозможно объединить столь противоречивые стороны, аспекты, формы, т.к. одна исключает другую. Юридическая ответственность - феномен социальной действительности, следовательно, к нему применим, как и к любым процессам действительности, основополагающий принцип диалектики - рассматривать все явления социальной жизни в их противоречивом единстве и борьбе. Следовательно, если подойти к этому явлению с позиций традиционной логики и диалектики, то такой анализ непременно приводит к выводу: юридическая ответственность едина, а ее различные формы реализации находятся в постоянной «борьбе». Правонарушение существует постольку, поскольку есть правомерное поведение, а государственно-принудительная форма реализации юридической ответственности существует лишь постольку, поскольку существует добровольная форма реализации юридической ответственности.

Юридическая ответственность, как и любой другой вид социальной ответственности едина и включает в себя как ответственность за будущее поведение (позитивную, добровольную) ответственность, так и ответственность за прошлое противоправное поведение (негативную, государственно-принудительную ответственность). Утверждать об отсутствии у юридической ответственности добровольной формы реализации, равнозначно признанию юридической ответственности не разновидностью социальной ответственности, а не- 
ким особым «несоциальным видом» и исключению ее из системы регулирования общественных отношений.

К сторонникам только принудительной формы реализации юридической ответственности возникает один вопрос: если между юридической ответственностью и социальной ответственностью больше общего чем различий, то почему в исследованиях отрицается существование добровольной формы реализации юридической ответственности? Такое отрицание противоречит принципам историзма, конкретности истины, соотношению части и целого, философскому закону единства и борьбы противоположностей, правилам логики. Отрицание добровольной формы реализации юридической ответственности обедняет действительное содержание юридической ответственности, что порождает ограниченность многих научных исследований и не может не сказываться на качестве законности и правопорядка, разработке механизмов правомерного поведения.

Регулирование юридической ответственностью происходит путем установления управомоченного и обязанного поведения, запретов или велений совершать или не совершать определенные действия, а норма права выступает эталоном возможного или должного, а также ответственного поведения. По этому эталону определяется правомерность или противоправность действий, а правовая ответственность формализуется правовыми нормами, устанавливается ими. Установление статутной (единой ответственности) ответственности имеет место до факта правомерного или противоправного поведения $[18$, с. 80$]$. «Статутная ответственность - это объективно обусловленная, установленная законом и охраняемая государством необходимость (обязанность) осознанного и добровольного выполнения правовых предписаний участниками правоотношений. Она выполняет конструктивно-регулятивную функцию, является образцом (конструкцией, моделью) действительно ответственного и должного поведения» [18, с. 81]. Позитивный и негативный аспекты (формы. - авт.) реализации юридической ответственности представляют собой отношение субъектов правоотношений к статутной ответственности и выражаются в их поведении [18, с. 81]. Противники позитивной юридической ответственности не могут тут упрекнуть в том, что она лишена юридического содержания. Юридическая ответственность едина, но имеет различные аспекты (формы) реализации. «Право - не только мера юридической свободы, но и мера юридической ответственности. Это корреляционные категории ... ответственность - такая же объективная необходимость, как и свобода» [19, с. 23].
Правовая норма как разновидность социальной нормы выступает в качестве нормативной основы юридической ответственности. Глубинные основания юридической ответственности состоят во включенности субъекта в общественные отношения и в его связанности предъявляемыми к нему требованиями. В правовой норме эти требования только формализуются и приобретают общеобязательный, властный, обеспечиваемый государственным принуждением характер. «Социальная ответственность обусловлена взаимосвязями между людьми, общностями, коллективами» [20, с. 17]; «социальным основанием ответственности выступает связь между личностью и обществом, социальная детерминация действий субъектов» [20, с. 15]. Общественные отношения и вытекающие из них требования находят свое закрепление в правовых нормах, которые начинают оказывать на них обратное регулирующее, развивающее, упорядочивающее воздействие.

В общей теории юридической ответственности дают о себе знать терминологическая перенасыщенность и отсутствие терминологической четкости. Существует обилие взглядов, подходов, аспектов, мнений и точек зрения, иногда взаимоисключающих. Позитивную юридическую ответственность называют: перспективной; интроспективной; правовой (противопоставляя тем самым юридической); умеренно-позитивной, активно-позитивной; надлежащим исполнением обязанностей; поощрительной. В свою очередь второй аспект ответственности называют: негативным, ретроспективным, пассивным и т.д.

Без сомнений разнообразие взглядов и названий можно объяснить сложностью и многогранностью рассматриваемого нами явления. Оно усложняется еще и тем, что нередко вся проблема юридической ответственности ограничивается ее «традиционным» ретроспективным аспектом. Однако, «традиционность понятий не может быть весомым аргументом в их пользу и «...вовсе не означает их «вечности». Они, как и все право в целом, олицетворяют социальную действительность, развиваются, видоизменяются, наполняются качественно новым содержанием» [21, c. 29]. Мы, наоборот полагаем, что направление исследования, сводящее юридическую ответственность только к ее негативному аспекту, является тупиковым. Оно обедняет социальную ценность данной категории, оставляя без внимания ее истоки, усилия, направленные на активизацию человеческой деятельности, развитие самостоятельности и инициативы, повышение действительно ответственного отношения граждан к правовым предписаниям. «Традиционное» направление 


\section{Право и политика 5 (185) • 2015}

исследования не может претендовать на незыблемость и непогрешимость. Не дает оно ответа и на практический вопрос: почему юридическая ответственность нередко не только неэффективная, но и вообще не срабатывает. Поэтому, не отрицая существования ретроспективной ответственности, полагаем, что она является лишь частью общей проблемы юридической ответственности, причем не определяющей, которую нельзя выдавать за целое [22, с. 206].

На основании изложенного возникают естественные вопросы. Почему до настоящего времени нет полной ясности в исследовании юридической ответственности? Что нужно предпринять в науке для того, чтобы этого добиться?

Ответ на первый вопрос. Полной ясности нет потому, что юридическая наука пока еще не разработала системного исследования правовой ответственности, хотя попытки в этом направлении имели место. Все суждения в основном сводятся к частностям - отрицательной реакции на совершенное правонарушение, которое является лишь следствием безответственности. Поэтому не случайно юридической ответственности даются определения, отождествляющие ее с иными правовыми категориями, чаще всего с государственным принуждением и его формами. Не видно объективного характера юридической ответственности, ибо преимущество отдается ее субъективным моментам (оценке, реакции на правонарушение, осуждению поведения и т.п.). Главной причиной всего и является ограничение юридической ответственности ретроспективным аспектом, когда любые попытки выхода за его пределы настойчиво отвергаются под необоснованным предлогом, что они, якобы, запутывают вопрос и ничего науке не дают. Почему же тогда, не смотря на огромную проделанную работу, вопрос до сих пор остается столь запутанным? Потому, что в сложившейся ситуации невозможно постичь ясности в исследовании ответственности, так как она представлена в усеченном варианте и далеко не второстепенные вопросы остаются вне поля зрения. В частности, речь идет об истоках, объективном характере, структуре правовой ответственности и системном взаимодействии ее элементов.

Отсюда вытекает ответ на второй поставленный вопрос. Для того, чтобы добиться полноты и ясности в исследовании юридической ответственности, необходимо сосредоточить внимание на изучении ее структуры, которая интегрировала бы в науке взгляды, являющиеся ступеньками на пути к новым решениям в познании данного явления.

В основу исследования юридической ответственно- сти должен быть положен структурный метод научный метод научного познания. Наряду с ним необходимо, разумеется, использовать и иные научные методы - диалектический, системно-функциональный, формальнологический, правового моделирования и другие.

Статутная (единая), добровольная и государственно-принудительная формы реализации - основные ее структурные элементы. Системность, диалектическое взаимодействие между ними, вся их «правовая жизнь» наиболее ярко проявляются в правовых связях и соответствующих отношениях, которые следует рассматривать в единстве различных аспектов их бытия - институциональном (статическом) и фактически поведенческом (динамическом).

Статутная (единая) ответственность носит объективный характер, установлена законом, является предпосылкой внешнего проявления ответственного или безответственного поведения. Истоки ответственности находятся в государственно-правовом регулировании общественных отношений, которое является непосредственной предпосылкой ее установления. Такого рода ответственность основана на нормах права, подвергается правовому оформлению, поэтому и называется юридической, т.е. носит нормативно-правовой характер.

Установление единой ответственности (ответственности как целостного явления, статутной ответственности) имеет место до факта правомерного или противоправного поведения, до его оценки как ответственного или безответственного. Она представляет собой общее требование для всех субъектов права, руководство к действию, к правильному выполнению правовых предписаний, является ориентиром должного поведения и критерием его оценки. Согласно логике, до реакции на юридически значимое поведение, его оценки как ответственного или безответственного государство первоначально должно установить, какие субъекты, при каких условиях, за что и в каком объеме несут ответственность, последствия на случай положительного (позитивного) или отрицательного (негативного) отношения к правовым установкам государственной власти.

Статутная (единая) ответственность - это объективно обусловленная, установленная законом и охраняемая государством обязанность (необходимость) соблюдения правовых предписаний участниками правоотношений, а в случае ее нарушения - обязанность правонарушителя претерпеть осуждение, ограничение прав имущественного или личного неимущественного характера. В статусной ответственности нормативно закреплены как добровольная, так и государственно-принудительная формы реализации юридической ответственности. На 
наш взгляд, именно такая постановка вопроса отвечает современным потребностям правового регулирования общественных отношений, т.к. добровольная форма реализации юридической ответственности без закрепления в нормах права государственно-принудительной формы реализации ответственности беззащитна, а государственно-принудительная форма реализации ответственности без добровольной бессмысленна. В определение ответственности как целостного правового явления мы включили (потенциально) и государственно-принудительную форму реализации, но это не означает, что она всегда реализуется. Однако она необходима, т.к. указывает субъекту какие неблагоприятные последствия наступят для него в случае нарушения нормы права. Наивно полагать, что все субъекты общественных отношений будут соблюдать предписания норм права только исходя из уважения к закону. Ответственность действенная и эффективна только в взаимодействии различных ее аспектов, которые в своей совокупности и составляют понятие ответственности как целостного правового явления.

Юридическая ответственность как целостное правовое явление является гарантией и существенной стороной правового положения личности. Наряду с иными гарантиями она направлена на создание реальных возможностей пользоваться правами и свободами, надлежаще выполнять обязанности. Иными словами, статутная ответственность ориентирует на то, что использование гражданами прав и свобод неотделимо от исполнения своих обязанностей, и не должно наносить ущерб интересам общества и государства, правам других граждан.

Мы именуем такую ответственность статутной (единой, целостным правовым явлением) на том основании, что она устанавливается законодательством. В действующей законодательстве формализованы правила ответственного поведения и последствия нарушения правил поведения. Иными словами, там предусмотрена как добровольная, так и государственно-принудительная формы реализации юридической ответственности, а также составы правомерного (ответственного) поведения и составы правонарушений (безответственного поведения).

Главным источником общего правового статуса личности, основное содержание которого составляют права и обязанности, является основной закон нашей страны - Конституция РФ, которая законодательно устанавливает этот статус для того, чтобы граждане, организации и должностные лица соблюдали конституционные нормы, ответственно относились к их предписаниям. Изложенное свидетельствует о том, что такие нормы не только закрепляют конституционные правовые отношения, но и возлагают на субъектов этих отношений ответственность. Последняя непосредственно вытекает из требований норм права и представляет собой всеобщую обязанность соблюдения Конституции РФ и иных подзаконных нормативно-правовых актов. Следовательно, законодательное установление статутной ответственности необходимо. Без закрепления в правовых нормах ответственности не может возникнуть состояние отношения к ней субъектов права. Данное структурное подразделение является юридической базой, первичным, отправным элементом юридической ответственности, исключение которого означало бы невозможность существования правовой ответственности вообще. Без права невозможно представить правовую ответственность, призрачным становится проявление состояния отношения к тому чего нет. Юридическая ответственность имеет значение управляющей системы, она установлена законом и является предпосылкой реализации юридической ответственности в любой общепризнанной форме ее реализации.

Мы полагаем, что изначально устанавливается статутная юридическая ответственность (юридическая ответственность как целостное правовое явление), а добровольная и государственно-принудительная и формы реализации непосредственно вытекают из нее. Из них первая более стабильна и фундаментальна. По отношению к ней все субъекты права и участники правоотношений находятся в одинаковом правовом положении (состоянии ответственности), обязаны сообразовывать свое поведение с предписаниями законодателя, за что и несут ответственность. Только при соблюдении этого принципиального положения поведение можно считать юридически ответственным, но не правонарушителя, как еще нередко полагают.

Единая ответственность - это объективно закрепленная в нормах права целевая установка, ориентир должного поведения субъектов права и критерий его оценки как ответственного или безответственного, что позволяет субъекту еще не совершившему юридически значимого деяния заранее знать о своей ответственности, что дисциплинирует и сосредотачивает его на выполнении общих законодательных правил. Если он их соблюдает, то поступает юридически ответственно, в противном случае - безответственно. Сообразно поступкам наступают и последствия, что вполне соответствует общеправовому принципу справедливости.

Следовательно, исключение ответственности, которая включает в себя различные формы реализации, 
DOI: $10.7256 / 1811-9018.2015 .5 .14470$

При цитировании этой статьи сноска на dоі обязательна

\section{Право и политика 5 (185) • 2015}

означало бы исчезновение ориентирующей цели, критерия оценки юридически значимого поведения как ответственного или безответственного. Ответственность как целостное правовое явление находится в статическом состоянии. Она является основанием, причиной и усло- вием возникновения добровольной формы реализации ответственности, критерием ее определения как таковой. Без этого условия невозможно появление последующей позитивной ответственности, которая представляет собой ответственность в динамическом состоянии.

\section{Библиография:}

1. Косолапов Р., Марков В. Свобода и ответственность. - М.: Изд-во Полит. лит-ры, 1969.

2. Кант И. Сочинения. В 6 т. Т. 4. - М.: Мысль, 1965. Алексеев П.В., Панин А.В. Философия. -М.: Изд-во Проспект, 2003. Базылев Б.Т. Юридическая ответственность. - Красноярск: Изд-во Красноярского ун-та, 1985.

3. Марченко Н.М., Лейст О.Э. и др. Общая теория государства и права. Академический курс лекций / Под ред. М.Н. Марченко Т. 2. - М., 1998.

4. Грядунова Л.И. Социальная ответственность личности в условиях развитого социализма. - Киев, 1979.

5. Ильин И.А. Путь к очевидности. - М., 1993.

6. Ц Царьков И.И. Философские и государственно-правовые взгляды Джона Локка. - Тольятти: Изд-во МАБиБД, 1996.

7. Черменина А. П. Проблема ответственности в этике: Автореф. дис. ... канд. филос. наук. - Л., 1965.

8. Кудрявцев В. Н. Закон, поступок, ответственность. - М.: Наука, 1986

9. Сперанский В.И. Социальная ответственность в системе общественных отношений (социальный аспект): Автореф. дис. д-ра. ... филос. наук. - М., 1990

10. Ореховский А.И. Ответственность и ее социальная природа (методологический аспект). - Томск, 1978.

11. Плахотный А.Ф. Свобода и ответственность (социологический аспект) - Харьков: Изд-во Харьков. ун-та, 1972.

12. Сафаров. Н.С. Проблема моральной ответственности. - Баку: РИО ДГУ, 1985.

13. Трофимова М.П. Функции юридической ответственности: Автореф. дис. ... канд. юрид. наук. - Саратов, 2000.

14. Медушевский А.Н. История русской социологии. - М., 1993.

15. Мироненко М.Б. Принципы юридической ответственности в системе принципов права: Автореф. дис. ... канд. юрид. наук. - Саратов, 2001.

16. Базылев Б.Т. Юридическая ответственность. - Красноярск, 1985

17. Шабуров А.С. Политические и правовые аспекты социальной ответственности личности: Дис. ... д-ра. юрид. наук. Екатеринбург, 1992.

18. Черных Е.В. О нормативном характере юридической ответственности // Вопросы теории государства и права. Вып. 1(10). - Саратов: Изд-во СГАП, 1998.

19. Матузов Н.И. Право как мера свободы и ответственности личности: Межвуз. сб. науч. ст. // Атриум. Сер. «Юриспруденция». - Тольятти: Изд-во МА-БиБД, 1999. - № 1. - С. 20-26.

20. Филатова Т.И. Социальная ответственность как фактор преодоления отчуждения личности: Автореф. дис. ... канд. филос. наук. - Харьков, 1990.

21. Сенякин И.Н. Специализация и унификация российского законодательства: Автореф. дис. ....-ра юрид. наук. - Саратов, 1993.

22. Черных Е.В., Липинский Д.А. Юридическая ответственность как целостное правовое явление // Вестник Самарской государственной экономической академии. - Самара, 2005. - № 1. С. 75-87.

\section{References (transliterated):}

1. Kosolapov R., Markov V. Svoboda i otvetstvennost'. - M.: Izd-vo Polit. lit-ry, 1969.

2. Kant I. Sochineniya. V 6 t. T. 4. - M.: Mysl', 1965. Alekseev P.V., Panin A.V. Filosofiya. - M.: Izd-vo Prospekt, 2003. Bazylev B.T. Yuridicheskaya otvetstvennost'. - Krasnoyarsk: Izd-vo Krasnoyar-skogo un-ta, 1985.

3. Marchenko N.M., Leist O.E. i dr. Obshchaya teoriya gosudarstva i prava. Akade-micheskii kurs lektsii / Pod red. M.N. Marchenko T. 2. - M., 1998.

4. Gryadunova L.I. Sotsial'naya otvetstvennost' lichnosti v usloviyakh razvitogo sotsializma. - Kiev, 1979.

5. Il'in I.A. Put' k ochevidnosti. - M., 1993.

6. Tsar'kov I.I. Filosofskie i gosudarstvenno-pravovye vzglyady Dzhona Lok-ka. - Tol'yatti: Izd-vo MABiBD, 1996.

7. Chermenina A. P. Problema otvetstvennosti v etike: Avtoref. dis. ... kand. filos. nauk. - L., 1965.

8. Kudryavtsev V. N. Zakon, postupok, otvetstvennost'. - M.: Nauka, 1986

9. Speranskii V.I. Sotsial'naya otvetstvennost'v sisteme obshchestvennykh ot-noshenii (sotsial'nyi aspekt): Avtoref. dis. d-ra. ... filos. nauk. - M., 1990

10. Orekhovskii A.I. Otvetstvennost' i ee sotsial'naya priroda (metodologiche-skii aspekt). - Tomsk, 1978.

11. Plakhotnyi A.F. Svoboda i otvetstvennost' (sotsiologicheskii aspekt) - Khar'kov: Izd-vo Khar'kov. un-ta, 1972.

12. Safarov. N.S. Problema moral'noi otvetstvennosti. - Baku: RIO DGU, 1985. 
DOI: $10.7256 / 1811-9018.2015 .5 .14470$

При цитировании этой статьи сноска на dоі обязательна

Закон и правопорядок

13. Trofimova M.P. Funktsii yuridicheskoi otvetstvennosti: Avtoref. dis. ... kand. yurid. nauk. - Saratov, 2000.

14. Medushevskii A.N. Istoriya russkoi sotsiologii. - M., 1993.

15. Mironenko M.B. Printsipy yuridicheskoi otvetstvennosti v sisteme printsipov prava: Avtoref. dis. ... kand. yurid. nauk. - Saratov, 2001.

16. Bazylev B.T. Yuridicheskaya otvetstvennost'. - Krasnoyarsk, 1985

17. Shaburov A.S. Politicheskie i pravovye aspekty sotsial'noi otvetstvennosti lichnosti: Dis. ... d-ra. yurid. nauk. - Ekaterinburg, 1992.

18. Chernykh E.V. O normativnom kharaktere yuridicheskoi otvetstvennosti // Voprosy teorii gosudarstva i prava. Vyp. 1(10). Saratov: Izd-vo SGAP, 1998.

19. Matuzov N.I. Pravo kak mera svobody i otvetstvennosti lichnosti: Mezhvuz. sb. nauch. st. // Atrium. Ser. «Yurisprudentsiya». Tol'yatti: Izd-vo MA-BiBD, 1999. - № 1. - S. 20-26.

20. Filatova T.I. Sotsial'naya otvetstvennost' kak faktor preodoleniya otchuzhdeniya lichnosti: Avtoref. dis. ... kand. filos. nauk. Khar'kov, 1990.

21. Senyakin I.N. Spetsializatsiya i unifikatsiya rossiiskogo zakonodatel'stva: Avtoref. dis. ...d-ra yurid. nauk. - Saratov, 1993.

22. Chernykh E.V., Lipinskii D.A. Yuridicheskaya otvetstvennost' kak tselostnoe pravovoe yavlenie // Vestnik Samarskoi gosudarstvennoi ekonomicheskoi akademii. - Samara, 2005. - № 1. S. 75-87. 